OPEN ACCESS

Edited by: John T. Fisher,

Queen's University, Canada

Reviewed by:

Piergiuseppe Agostoni,

Centro Cardiologico Monzino

(IRCCS), Italy

Gabriele Valli,

Azienda Ospedaliera San Giovann

Addolorata, Italy

*Correspondence:

Pierantonio Laveneziana pierantonio.laveneziana@aphp.fr

Specialty section:

This article was submitted to

Respiratory Physiology,

a section of the journal

Frontiers in Physiology

Received: 20 April 2020

Accepted: 15 July 2020

Published: 05 August 2020

Citation:

Laveneziana $P$ and Weatherald $J$ (2020) Pulmonary Vascular Disease and Cardiopulmonary Exercise Testing. Front. Physiol. 11:964. doi: 10.3389/fphys.2020.00964

\section{Pulmonary Vascular Disease and Cardiopulmonary Exercise Testing}

\author{
Pierantonio Laveneziana ${ }^{1,2 \star}$ and Jason Weatherald ${ }^{3,4}$ \\ 1 Sorbonne Université, INSERM, UMR S1158 Neurophysiologie Respiratoire Expérimentale et Clinique, Paris, France, \\ ${ }^{2}$ AP-HP, Groupe Hospitalier Universitaire APHP-Sorbonne Université, Sites Pitié-Salpêtrière, Saint-Antoine et Tenon, Service \\ des Explorations Fonctionnelles de la Respiration, de l'Exercice et de la Dyspnée (Département R3S), Paris, France, \\ ${ }^{3}$ Division of Respirology, Department of Medicine, University of Calgary, Calgary, AB, Canada, ${ }^{4}$ Libin Cardiovascular Institute \\ of Alberta, University of Calgary, Calgary, $A B$, Canada
}

Cardiopulmonary exercise testing (CPET) is of great interest and utility for clinicians dealing Pulmonary Hypertension $(\mathrm{PH})$ in several ways, including: helping with differential diagnosis, evaluating exercise intolerance and its underpinning mechanisms, accurately assessing exertional dyspnea and unmasking its underlying often non-straightforward mechanisms, generating prognostic indicators. Pathophysiologic anomalies in $\mathrm{PH}$ can range from reduced cardiac output and aerobic capacity, to inefficient ventilation, dyspnea, dynamic hyperinflation, and locomotor muscle dysfunction. CPET can magnify the $\mathrm{PH}$-related pathophysiologic anomalies and has a major role in the management of $\mathrm{PH}$ patients.

Keywords: cardiopulmonary exercise testing, dyspnea, prognosis, pulmonary hypertension, dynamic hyperinflation, ventilatory inefficiency

\section{INTRODUCTION}

Pulmonary arterial hypertension (PAH) is characterized by anomalies in pulmonary arteries (abnormal proliferation of smooth muscle and endothelial cells) which results in cardiovascular anomalies such as increase in pulmonary vascular resistance (PVR) and finally right ventricular failure (Galie et al., 2015; Humbert et al., 2019; Simonneau et al., 2019). PAH may present with nonspecific symptoms and signs such as generalized fatigue, limitation of daily-activities and dyspnea, and this may prevent clinicians from diagnosing it early in the course of PAH and thus most of the time the diagnosis is made at the time of advanced right heart failure. Right-heart catheterization (RHC) is fundamental to confirm the diagnosis of PAH (Simonneau et al., 2019) and recently a new hemodynamic definition of PAH has been proposed (a mean pulmonary artery pressure $>20 \mathrm{mmHg}$ instead of previous one $\geq 25 \mathrm{mmHg}$ ) based on the analysis of large databases (Kovacs et al., 2017) and a meta-analysis of normal hemodynamics (Kovacs et al., 2009) in order to identify patients with early pulmonary vascular disease (Simonneau et al., 2019).

Cardiopulmonary exercise testing (CPET) is of great interest and utility for clinicians dealing $\mathrm{PH}$ in evaluating exercise intolerance and its underpinning mechanisms, accurately assessing exertional dyspnea and unmasking its underlying mechanisms, which are often not straightforward. Previous studies have shown that PAH management at an early stage of the disease translates into better outcomes (Galie et al., 2008; Humbert et al., 2011; Lau et al., 2015). Therefore, it appears crucial to establish early diagnosis and CPET can help clinicians in the differential diagnosis and evaluating prognosis in such an especially fragile population. 


\section{PATHOPHYSIOLOGIC RESPONSE-PROFILE TO EXERCISE IN PULMONARY HYPERTENSION}

CPET can magnify the PH-related pathophysiologic anomalies and has a major role in the management of $\mathrm{PH}$ patients. Pathophysiologic anomalies in $\mathrm{PH}$ can widely range from reduced cardiac output and aerobic capacity, to pulmonary gas exchange and ventilatory efficiency anomalies, dyspnea, dynamic hyperinflation and locomotor muscle dysfunction (Figure 1).

Pulmonary vascular obstruction along with concurrent increased mean PAP and PVR and reduced pulmonary capillary bed and recruitment give rise to three different pathophysiologic anomalies: (1) ventilation/perfusion (V/Q) inequalities; (2) pulmonary gas exchange anomalies; (3) increased right ventricle (RV) afterload and concomitant reduced left ventricle (LV) filling. These three major pathophysiologic derangements are responsible of characteristic anomalies observed during CPET that can ultimately explain exertional dyspnea and exercise intolerance (Figure 1).

V/Q inequalities can manifest with either low V/Q ratios and shunt (right to left shunt through a patent foramen ovale, for example) or high V/Q ratios caused by increased minute ventilation $\left(\mathrm{V}_{\mathrm{E}}^{\prime}\right)$ of poorly perfused air spaces (Oudiz et al., 2010) V/Q mismatching can result in hypoxemia (reduced arterial partial pressure of oxygen, $\mathrm{PaO}_{2}$ ), high dead space to tidal volume fraction $\left(\mathrm{V}_{\mathrm{D}} / \mathrm{V}_{\mathrm{T}}\right)$ and widening of the alveolararterial pressure difference of oxygen $\left[\mathrm{P}(\mathrm{A}-\mathrm{a}) \mathrm{O}_{2}\right]$ and of the arterial-end-tidal pressure difference of carbon dioxide $[\mathrm{P}(\mathrm{a}-$ ET) $\mathrm{CO}_{2}$ ]. These anomalies can stimulate an excessive $\mathrm{V}_{\mathrm{E}}{ }_{\mathrm{E}}$ response to exercise along with altered chemosensitivity and inefficient ventilation mirrored by the increased steepness with which $V_{E}^{\prime}$ rises with respect to $\mathrm{CO}_{2}$ production $\left(\mathrm{V}^{\prime} \mathrm{CO}_{2}\right)$ (i.e., increased $\mathrm{V}_{\mathrm{E}}^{\prime} / \mathrm{V}^{\prime} \mathrm{CO}_{2}$ slope) (D'Alonzo et al., 1987; Riley et al., 2000; American Thoracic Society, 2003; Velez-Roa et al., 2004; Naeije and van de Borne, 2009; Wensel et al., 2009; Laveneziana et al., 2013b; Farina et al., 2018; Weatherald et al., 2020). Inefficient ventilation and altered chemosensitivity translate into increase ventilatory demand, $\mathrm{V}_{\mathrm{E}}{ }_{\mathrm{E}} / \mathrm{V}^{\prime} \mathrm{CO}_{2}$ and $\mathrm{V}_{\mathrm{D}} / \mathrm{V}_{\mathrm{T}}$, decrease end-tidal pressure of carbon dioxide $\left(\mathrm{P}_{\mathrm{ET}} \mathrm{CO}_{2}\right)$ and hypocapnia (reduced arterial partial pressure of carbon dioxide, $\mathrm{PaCO}_{2}$ ) (Riley et al., 2000; Yasunobu et al., 2005; Zhai et al., 2011; Scheidl et al., 2012; Godinas et al., 2017; Weatherald et al., 2020).

The reduced pulmonary capillary bed and recruitment at rest can be amplified during CPET and translated in pulmonary gas exchange anomalies such as a relative low alveolar-capillary diffusing capacity; this can be mirrored by a reduced diffusing capacity or transfer factor of the lung for carbon monoxide (DLCO or TLCO) at rest and a reduced $\mathrm{PaO}_{2}$ with enlargement of $\mathrm{P}(\mathrm{A}-\mathrm{a}) \mathrm{O}_{2}$ during CPET.

Impaired cardiac function (due to increased RV afterload and concomitant reduced LV filling) along with peripheral muscle dysfunction and deconditioning (Bauer et al., 2007; Tolle et al., 2008; Mainguy et al., 2010; Dimopoulos et al.,
2013) result in reduced cardiac output and blood flow to the periphery. This translates to reduced oxygen delivery to working locomotor muscles and reduced venous pressure of oxygen $\left(\mathrm{PvO}_{2}\right)$, which results in reduced aerobic capacity with attendant reduced anaerobic threshold (AT) and oxygen consumption $\left(\mathrm{V}^{\prime} \mathrm{O}_{2}\right)$. Reduced oxygen delivery also causes early onset of lactic acidosis and increased $\mathrm{V}^{\prime} \mathrm{CO}_{2}$, which further contributes to the excessive $\mathrm{V}_{\mathrm{E}}^{\prime}$ response to CPET (Nootens et al., 1995; Sun et al., 2001; Deboeck et al., 2004; Hasler et al., 2016; Naeije and Badagliacca, 2017; Weatherald et al., 2018a). The reduced mixed venous $\mathrm{O}_{2}$ content from altered cardiac output can also contribute and amplify exertional hypoxemia.

Mechanical anomalies on tidal volume $\left(\mathrm{V}_{\mathrm{T}}\right)$ expansion and dynamic lung hyperinflation can also play a crucial role into the genesis of exertional dyspnea and therefore exercise intolerance (Richter et al., 2012; Laveneziana et al., 2013b, 2015; Manders et al., 2016; Boucly et al., 2020), and can be easily detected during CPET (Laveneziana et al., 2013b, 2015; Boucly et al., 2020).

\section{PERIPHERAL MUSCLE DYSFUNCTION}

Deconditioning and peripheral muscle abnormalities are important contributors to exercise intolerance. In chronic heart failure, which shares similar limitations in cardiac output reserve as $\mathrm{PAH}$ and $\mathrm{CTEPH}$, oxygen transport and diffusion at the level of skeletal muscle are abnormal (Esposito et al., 2010). Tissue oxygen saturation, oxygen extraction and muscle microcirculatory function may be impaired to an even greater degree in $\mathrm{PAH}$ compared with left heart failure (Tolle et al., 2008; Dimopoulos et al., 2013). Peripheral muscle in PAH patients is structurally and functionally abnormal, with a lower relative proportion of type I fibers and reduced quadriceps, forearm, and respiratory muscle strength compared to controls, which may be an important determinant of low peak $\mathrm{V}^{\prime} \mathrm{O}_{2}$ (Bauer et al., 2007; Mainguy et al., 2010).

Respiratory muscle strength has also been shown to be about 40\% lower in CTEPH patients (Manders et al., 2016). The mechanism of generalized skeletal muscle dysfunction in PAH may be a result of microcirculation rarefaction and an imbalance in angiogenic factors (Potus et al., 2014). Improvements in exercise capacity with exercise training in individuals with heart failure or peripheral vascular disease (Duscha et al., 2011) have been linked to improvements in skeletal muscle microcirculatory density, capillary-to-fiber ratio and mitochondrial volume (Esposito et al., 2011), which may be mechanisms by which training can improve exercise capacity in stable patients with PAH (Mereles et al., 2006; Ehlken et al., 2016). Peripheral muscle dysfunction is a potential relevant e hidden factor that can worsen the prognosis of $\mathrm{PAH}$ patients. Recently, Valli et al. have pointed out that patients with PAH may present with less efficient muscular oxygen utilization than healthy controls. Notably high energy expenditure had a relevant independent prognostic impact (Valli et al., 2019). 


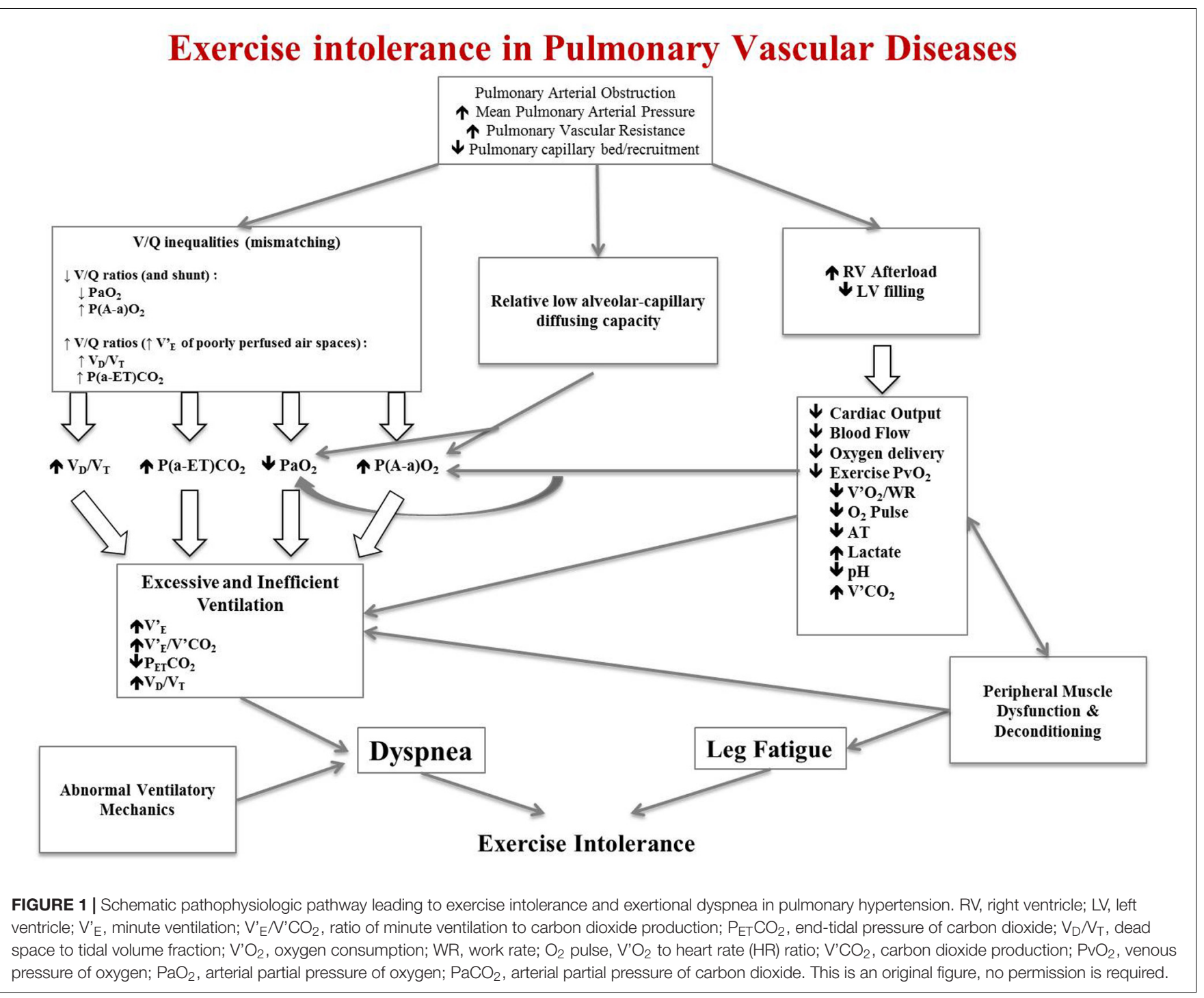

\section{TRANSLATING PH-RELATED PATHOPHYSIOLOGIC ANOMALIES INTO CPET VARIABLES: EXPLORING FACTORS EXPLAINING EXERCISE LIMITATION IN PH}

One of the indications of CPET is to explore the underlying mechanisms of exertional dyspnea and to detect mechanisms of exercise intolerance. Table 1 summarizes the main CPETderived variables defining ventilatory, respiratory mechanical, cardiovascular and pulmonary vascular limitation accompanied or not by gas exchange anomalies to exercise.

Two variables are used to detect exercise intolerance (Radtke et al., 2019) peak $V^{\prime} \mathrm{O}_{2}$ during an incremental CPET has well defined normal values (Puente-Maestu et al., 2018) and $\mathrm{V}^{\prime} \mathrm{O}_{2}$ at the anaerobic/ventilatory threshold (AT) has the advantage of being an effort independent measure of exercise tolerance (Agusti et al., 1997; ATS/ACCP, 2003; Palange et al., 2007; Puente-Maestu et al., 2016; Huckstepp et al., 2018). The disadvantage is that it relies on pattern recognition for accurate detection (which may differ from operator to operator due to lack of experience or inaccurate detection related to software - never trust software for detecting AT! - or wrong pattern recognition) and some severely impaired PH patients may not be able to attain the AT despite a good effort.

Cardiovascular limitation to exercise is not straightforward and may be defined by certain interrelated variables (Table 1). A reduced slope or late plateau of the $\mathrm{V}^{\prime} \mathrm{O}_{2}$ trajectory (i.e., a reduced $\mathrm{V}^{\prime} \mathrm{O}_{2}$ /work rate relationship $\leq 8$ ), or plateau (early or late during exercise) of the oxygen pulse $\left(\mathrm{V}^{\prime} \mathrm{O}_{2}\right.$ to heart rate ratio, i.e., $\left.\mathrm{V}^{\prime} \mathrm{O}_{2} / \mathrm{HR}\right)$, or an abnormal $\mathrm{HR} / \mathrm{V}^{\prime} \mathrm{O}_{2}$ slope ( $\left.>50\right)$ may be typical (Palange et al., 2018).

Pulmonary vascular limitation to exercise is not straightforward as well and may rely on evidence of increased $\mathrm{V}_{\mathrm{E}}{ }_{\mathrm{E}} / \mathrm{V}^{\prime} \mathrm{CO}_{2}$ slope and ratio at $\mathrm{AT}$ in addition to the abovementioned anomalies (Weatherald et al., 2018b). Other typical features of pulmonary vascular disease are low levels of 
TABLE 1 | Variables defining ventilatory and respiratory mechanical limitation (left panel) accompanied or not by gas exchange anomalies to exercise, and variables defining cardiovascular and pulmonary vascular limitation (right panel) accompanied or not by gas exchange anomalies to exercise.

\begin{tabular}{|c|c|}
\hline $\begin{array}{l}\text { Ventilatory and respiratory } \\
\text { mechanical limitation to exercise }\end{array}$ & $\begin{array}{l}\text { Cardiovascular and pulmonary } \\
\text { vascular limitation to exercise }\end{array}$ \\
\hline $\mathrm{BR}<15-20 \%$ & $\mathrm{BR}>15-20 \%$ \\
\hline $\begin{array}{l}\text { Dynamic Hyperinflation (decrease in IC } \\
>140 \mathrm{~mL} \text { ) }\end{array}$ & $\mathrm{V}^{\prime} \mathrm{O}_{2} / \mathrm{HR}<70 \%$ \\
\hline $\mathrm{V}_{\mathrm{T}}$ plateau & $\mathrm{V}^{\prime} \mathrm{O}_{2}$ Mork Rate $\downarrow$ \\
\hline $\begin{array}{l}\mathrm{RR}>50-55 \text { breaths/min (if restrictive } \\
\text { pattern) }\end{array}$ & Flat (and declining) V'O2/HR trajecton \\
\hline $\begin{array}{l}\mathrm{V}_{\mathrm{T}}=\mathrm{IC} \text { or }>60 \% \mathrm{VC} \text { (if restrictive } \\
\text { pattern) }\end{array}$ & Abnormal HR/V'O 2 slope (>50) \\
\hline HR peak < HR predicted & Chronotropic incompetence \\
\hline EILV > 90\% TLC at peak exercise & $\begin{array}{l}\text { Abnormal blood pressure response to } \\
\text { exercise }\end{array}$ \\
\hline $\mathrm{V}_{\top} / \mathrm{IC}>70 \%$ at peak exercise & ECG abnormalities during exercise \\
\hline \multicolumn{2}{|l|}{$\begin{array}{l}\text { The tidal inspiratory flow }>50 \text { to } 70 \% \\
\text { maximal inspiratory flow (in health } \\
<50-70 \% \text { ) }\end{array}$} \\
\hline With or without & With or without \\
\hline Gas exchange anomalies: & Gas exchange anomalies: \\
\hline$V_{D} N_{T} \uparrow$ & $V_{D} N_{T} \uparrow$ \\
\hline $\mathrm{P}(\mathrm{A}-\mathrm{a}) \mathrm{O}_{2} \uparrow$ & $\mathrm{P}(\mathrm{A}-\mathrm{a}) \mathrm{O}_{2} \uparrow$ \\
\hline Decrease of $\mathrm{PaO}_{2} \geq 10 \mathrm{mmHg}$ & Decrease of $\mathrm{PaO}_{2} \geq 10 \mathrm{mmHg}$ \\
\hline $\begin{array}{l}\text { Decrease of } \mathrm{SpO}_{2} \geq 5 \% \text { and/or } \\
\mathrm{SpO}_{2} \text { peak } \leq 88 \%\end{array}$ & $\begin{array}{l}\text { Decrease of } \mathrm{SpO}_{2} \geq 5 \% \text { and/or } \\
\mathrm{SpO}_{2} \text { peak } \leq 88 \%\end{array}$ \\
\hline $\mathrm{PaCO}_{2}$ peak > 45-50 mmHg & \\
\hline
\end{tabular}

BR, breathing reserve; IC, Inspiratory Capacity; VT, tidal volume; RR, Respiratory Rate; VC, Vital Capacity; HR, Heart Rate; EILV, End-Inspiratory Lung Volume; VD/VT, dead space to tidal volume fraction; $P(A-a) \mathrm{O}_{2}$, alveolar-arterial pressure difference of oxygen; $\mathrm{PaO}_{2}$, partial pressure of oxygen; $\mathrm{SpO}_{2}$, pulse oximetry saturation; $\mathrm{PaCO}_{2}$, arterial partial pressure of carbon dioxide; $\mathrm{V}^{\prime} \mathrm{O}_{2}$, oxygen consumption; $P(a-E T) C_{2}$, arterial-end-tidal pressure difference of carbon dioxide; $\downarrow$, reduced; $\uparrow$, increased.

$\mathrm{P}_{\mathrm{ET}} \mathrm{CO}_{2}$ at $\mathrm{AT}$, a $\mathrm{V}_{\mathrm{D}} / \mathrm{V}_{\mathrm{T}}$ which remains stable or increases or fails to decrease from baseline, a $\mathrm{P}(\mathrm{a}-\mathrm{ET}) \mathrm{CO}_{2}$ which fails to became negative during exercise and, sometimes, a $\mathrm{P}(\mathrm{A}-\mathrm{a}) \mathrm{O}_{2}$ which widens on exertion (Weatherald et al., 2020; Table 1). Of note, it should be pointed out that the finding of high $\mathrm{V}_{\mathrm{E}}^{\prime} / \mathrm{V}^{\prime} \mathrm{CO}_{2}$ at $\mathrm{AT}(\geq 34-35)$ and low $\mathrm{P}_{\mathrm{ET}} \mathrm{CO}_{2}$ at $\mathrm{AT}(\leq 30 \mathrm{mmHg})$ without an alternative explanation in patients presenting with unexplained dyspnea and exercise limitation should prompt further diagnostic testing to exclude PAH or CTEPH (Weatherald et al., 2018b) particularly in those patients with risk factors, such as prior venous thromboembolism, systemic sclerosis or a family history of PAH. These gas exchange anomalies are usually not found in patients with pulmonary venous hypertension secondary to cardiac diseases (Weatherald et al., 2018b). Associated low level of hemoglobin will enhance oxygen flow deficiency. Ischemic heart disease or cardiomyopathy may present with electrocardiographic or blood pressure anomalies during CPET (Palange et al., 2018).

Pulmonary gas exchange limitation to exercise is not straightforward as well and may rely on evidence of inefficient carbon dioxide exchange which can be signaled by high $V_{D} / V_{T}$ and often by high exercise $\mathrm{V}^{\prime}{ }_{\mathrm{E}} / \mathrm{V}^{\prime} \mathrm{CO}_{2}$ (Figure 2) or (alone or in combination with) inadequate oxygen exchange signaled by low $\mathrm{PaO}_{2}$ or, less directly, by desaturation at pulse oximetry.

Elevated $\mathrm{V}_{\mathrm{E}} / \mathrm{V}^{\prime} \mathrm{CO}_{2}$ (ventilatory inefficiency) and reduced resting $\mathrm{PaCO}_{2}$ (hypocapnia) are frequent in pulmonary vascular disease such as $\mathrm{PAH}$, chronic thromboembolic pulmonary hypertension (CTEPH) and pulmonary veno-occlusive disease (PVOD) (Weatherald et al., 2018b) and correlate with negative prognosis (Hoeper et al., 2007; Deboeck et al., 2012; Schwaiblmair et al., 2012; Groepenhoff et al., 2013). Abnormally reduced resting $\mathrm{PaCO}_{2}$ signals augmented chemosensitivity or an abnormal $\mathrm{PaCO}_{2}$ set-point. A low resting $\mathrm{PaCO}_{2}$ predicts a worse prognosis in PAH (Hoeper et al., 2007). However, high $\mathrm{V}_{\mathrm{D}} / \mathrm{V}_{\mathrm{T}}$ does not cause low resting $\mathrm{PaCO}_{2}$, therefore an altered $\mathrm{PaCO}_{2}$ set-point, increased neural respiratory drive, and/or increased chemosensitivity must explain hypocapnia and consequently, the high $\mathrm{V}_{\mathrm{E}}^{\prime} / \mathrm{V}^{\prime} \mathrm{CO}_{2}$ slope. Several factors such as metabolic acidosis, hypoxemia, baroreceptors in the pulmonary vessels and abnormal activation of the sympathetic nervous system have an influence on the $\mathrm{PaCO}_{2}$ set-point (Wasserman et al., 1975; Whipp and Ward, 1998; Sun et al., 2002; Velez-Roa et al., 2004; Wensel et al., 2004; Laveneziana et al., 2013b; Weatherald et al., 2018c). The evaluation of chemosensitivity and/or the $\mathrm{PaCO}_{2}$ set-point during exercise is difficult and can be problematic. Autonomic dysfunction, increased sympathetic nervous system activity, and an altered $\mathrm{CO}_{2}$ set-point relate to chemoreflex sensitivity. Recently Farina et al. (2018) performed minute-to-minute blood gas analysis during exercise in 18 patients with pulmonary vascular disease. They run hypoxic and hypercapnic challenge tests to assess peripheral and central chemosensitivity and found an increase in chemoreceptor sensitivity in both PAH and CTEPH that did not correlate (the peripheral chemoreceptor responses to hypoxia and hypercapnia) with any exercise variables. The "non-invasive" evaluation of the $\mathrm{PaCO}_{2}$ set-point during exercise is extremely difficult; one method is to assess the maximal end-tidal $\mathrm{CO}_{2}$ pressure (maximal $\mathrm{P}_{\mathrm{ET}} \mathrm{CO}_{2}$ ) value between the AT and respiratory compensation point where $\mathrm{P}_{\mathrm{ET}} \mathrm{CO}_{2}$ is constant and, therefore, is supposed to truly reflect the real $\mathrm{PaCO}_{2}$ set-point (Agostoni et al., 2002; Agostoni et al., 2010; Laveneziana et al., 2010). Recently, Weatherald et al. have pointed out that patients with resting hypocapnia (PAH, $n=34$; CTEPH, $n=19$; PVOD, $n=6$ ) had worse cardiac function and more severe gas exchange anomalies during CPET (Weatherald et al., 2020). High chemosensitivity and an altered $\mathrm{PaCO}_{2}$ set-point were likely explanations for resting hypocapnia and high $\mathrm{V}^{\prime}{ }_{\mathrm{E}} / \mathrm{V}^{\prime} \mathrm{CO}_{2}$ on exertion. The $\mathrm{PaCO}_{2}$ set-point, estimated by the maximal $\mathrm{P}_{\mathrm{ET}} \mathrm{CO}_{2}$ was the strongest correlate of peak exercise capacity and $\mathrm{V}_{\mathrm{E}}{ }_{\mathrm{E}} / \mathrm{V}^{\prime} \mathrm{CO}_{2}$, suggesting that this variable could be used as a non-invasive measure of disease severity even during submaximal exercise (Weatherald et al., 2020). Taken together, the results of the two studies from Weatherald et al. (2020) and Farina et al. (2018) imply that hypocapnic patients and/or those with low maximal $\mathrm{P}_{\mathrm{ET}} \mathrm{CO}_{2}$ during exercise have autonomic dysfunction and a lower $\mathrm{CO}_{2}$ set-point. Thus, resting $\mathrm{PaCO}_{2}$ or maximal $\mathrm{P}_{\mathrm{ET}} \mathrm{CO}_{2}$ on exertion could be used to identify patients with probably autonomic dysfunction or to help develop future 


\section{Ventilatory Efficiency}

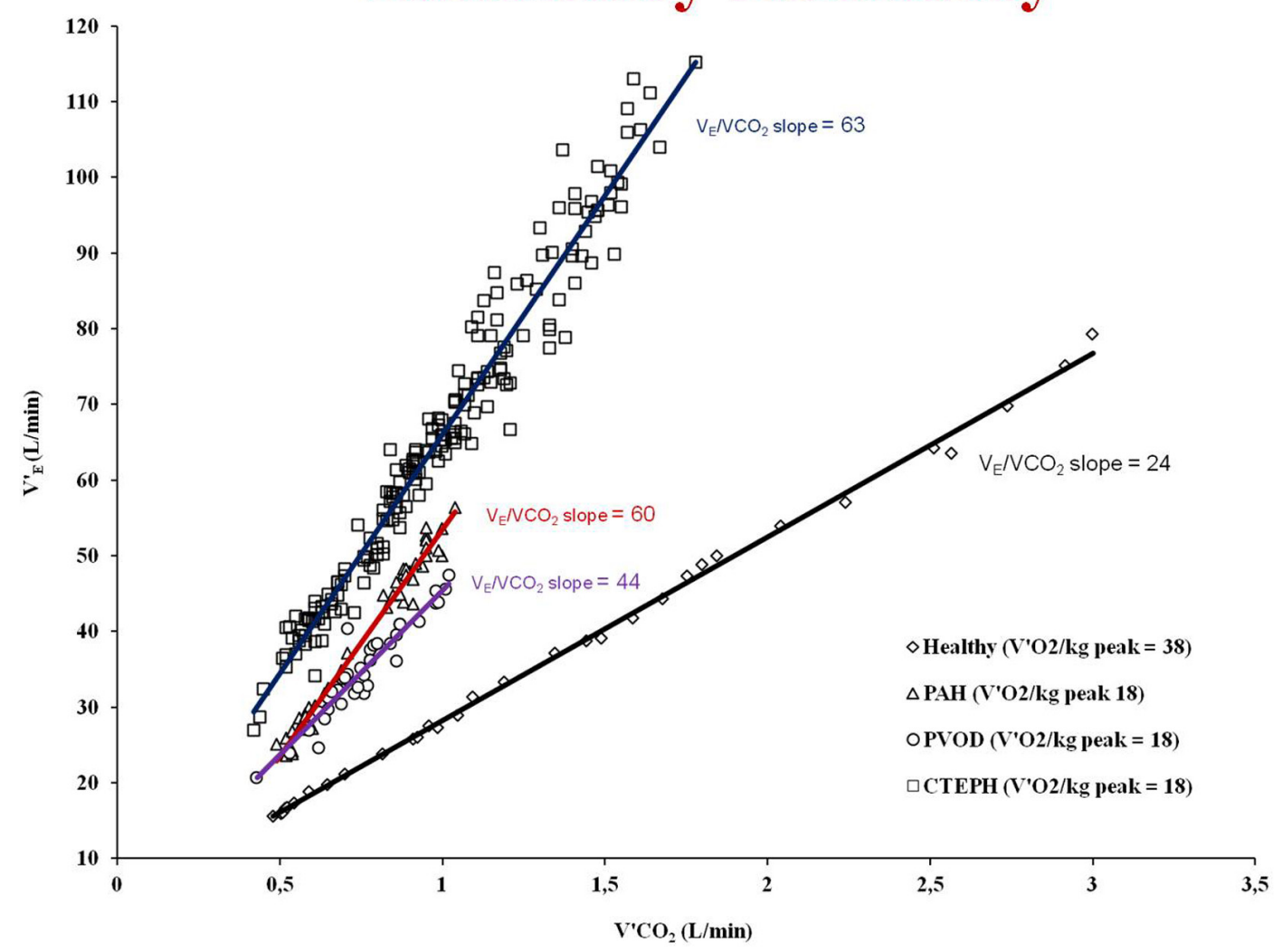

FIGURE 2 | Examples of ventilatory efficiency $\left(\mathrm{V}^{\prime} \mathrm{N} \mathrm{N}^{\prime} \mathrm{CO}_{2}\right.$ slope) in a healthy subject with a peak oxygen uptake $\left(\mathrm{V}^{\prime} \mathrm{O}_{2}\right)$ of $38 \mathrm{~mL} / \mathrm{Kg} / \mathrm{min}$ (black line and rhomboid), in a patient with pulmonary veno-occlusive disease (PVOD) with a peak $\mathrm{V}^{\prime} \mathrm{O}_{2}$ of $18 \mathrm{~mL} / \mathrm{Kg} / \mathrm{min}$ (violet line and circles), in a patient with pulmonary arterial hypertension $(\mathrm{PAH})$ with a peak $\mathrm{V}^{\prime} \mathrm{O}_{2}$ of $18 \mathrm{~mL} / \mathrm{Kg} / \mathrm{min}$ (red line and triangles) and in a patient with chronic thromboembolic pulmonary hypertension (CTEPH) with a peak V'O ${ }_{2}$ of $18 \mathrm{~mL} / \mathrm{Kg} / \mathrm{min}$ (blue line and squares). This is an original figure, no permission is required.

studies that target the sympathetic nervous system in pulmonary vascular disease.

Ventilatory limitation to exercise can also be detected in some $\mathrm{PH}$ patients during CPET (Table 1). Beside the wellknown breathing reserve, i.e., the comparison of peak $\mathrm{V}_{\mathrm{E}}^{\prime}$ to MVV (maximal voluntary ventilation), other indicators of ventilatory limitation to exercise can be appreciated: constraints on dynamic $\mathrm{V}_{\mathrm{T}}$ expansion relative to resting or dynamic decrease in inspiratory capacity (IC) used also to appreciate a critical reduction in inspiratory reserve volume (IRV) (Table 1; Laveneziana et al., 2013b, 2015; Boucly et al., 2020). More recently, evidence of ventilatory limitation has been suggested by the occurrence of important expiratory flow limitation (EFL) $>25 \%$ at peak exercise (Johnson et al., 1999; Palange et al., 2007; Puente-Maestu et al., 2016; Huckstepp et al., 2018) and some other indicators of mechanical ventilatory limitations to exercise such as end-inspiratory lung volume (EILV) > 90\% TLC alone or in combination with $\mathrm{V}_{\mathrm{T}} / \mathrm{IC}>70 \%$ at peak exercise have recently been observed in some patients with pulmonary vascular disease (Table 1). Figure 3 represents the typical exercise response profile of a $\mathrm{PAH}$ patient undergoing maximal incremental symptom-limited CPET. Table 2 summarizes the main alterations that can be observed in patients with pulmonary vascular disease during CPET.

\section{MECHANISMS EXPLAINING EXERTIONAL DYSPNEA IN PH}

Exertional dyspnea is most frequent and cumbersome symptom in patients with idiopathic PAH, CTEPH, and PVOD (Laveneziana et al., 2013b, 2014a, 2015; Laviolette and Laveneziana, 2014; Boucly et al., 2020; Figure 4).

Although researchers have worked hard to try to explain this symptom, its underpinning mechanisms remain at present not completely understood (Laveneziana et al., 2013b, 2014a, 2015; Laviolette and Laveneziana, 2014; Boucly et al., 2020). Previous research has particularly emphasized the cardio-andpulmonary-vascular factors contributing to exertional dyspnea (Sun et al., 2001) by pointing out the effects of combined impaired cardiac function and abnormal pulmonary gas exchange on exertion as the result of primary anomalies of pulmonary vessels on the increased ventilatory drive and therefore on the resultant exertional dyspnea (Sun et al., 2001). Nonetheless, 


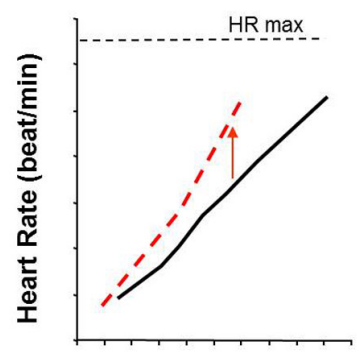

$\mathrm{VO}_{2}(\mathrm{ml} / \mathrm{kg} / \mathrm{min})$

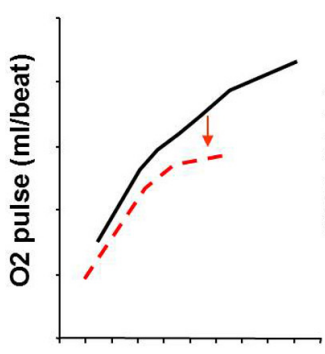

$\mathrm{VO}_{2}(\mathrm{ml} / \mathrm{kg} / \mathrm{min})$

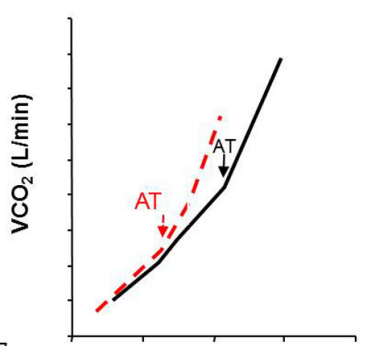

$\mathrm{VO}_{2}(\mathrm{~L} / \mathrm{min})$

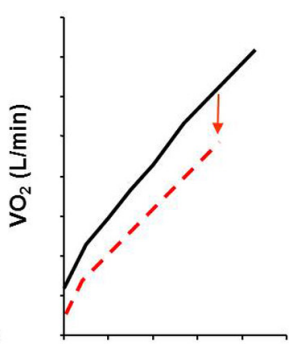

Work rate (watts)

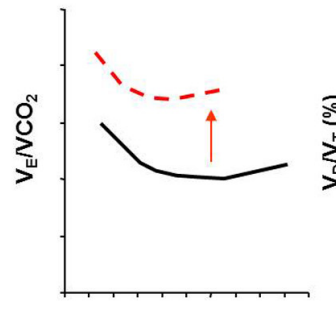

$\mathrm{VO}_{2}(\mathrm{ml} / \mathrm{kg} / \mathrm{min})$

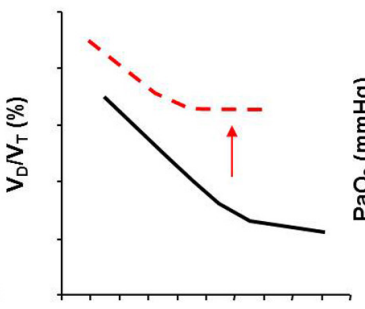

$\mathrm{VO}_{2}(\mathrm{ml} / \mathrm{kg} / \mathrm{min})$

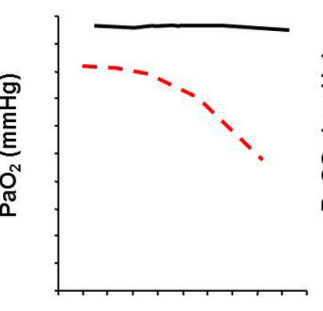

$\mathrm{VO}_{2}(\mathrm{ml} / \mathrm{kg} / \mathrm{min})$

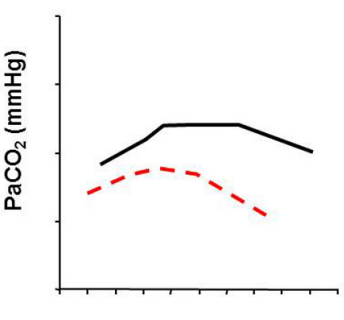

$\mathrm{VO}_{2}(\mathrm{ml} / \mathrm{kg} / \mathrm{min})$

FIGURE 3 | Typical exercise response profile of a PAH patient (red dotted line) compared with healthy control (black line) undergoing maximal incremental symptom-limited CPET. Abbreviations in the text. This is an original figure, no permission is required.

TABLE 2 | Typical CPET anomalies in patients with pulmonary vascular diseases

\begin{tabular}{|c|c|c|c|c|}
\hline & & РAH & СТЕРН & PVOD \\
\hline \multirow{4}{*}{$\begin{array}{l}\text { Metabolic and } \\
\text { cardiovascular }\end{array}$} & Peak V'O 2 & $\downarrow$ & $\downarrow$ & $\downarrow$ \\
\hline & $\mathrm{V}^{\prime} \mathrm{O}_{2}$ at $\mathrm{AT}$ & $\downarrow$ & $\downarrow$ & $\downarrow \downarrow$ \\
\hline & $\mathrm{V}^{\prime} \mathrm{O}_{2} / \mathrm{WR}$ & $\downarrow$ & $\downarrow$ & $\downarrow$ \\
\hline & $\mathrm{O}_{2}$ pulse & $\downarrow$ & $\downarrow$ & $\downarrow$ \\
\hline \multirow{3}{*}{$\begin{array}{l}\text { Ventilation and } \\
\text { mechanics }\end{array}$} & Peak V'E & $\downarrow$ & $\downarrow$ & $\downarrow$ \\
\hline & Breathing Reserve & Normal & Normal & Normal \\
\hline & Dynamic hyperinflation & Possible & Possible & $?$ \\
\hline \multirow[t]{7}{*}{ Gas exchange } & V'EN'COO 2 slope & $\uparrow$ & $\uparrow \uparrow$ & $\uparrow \uparrow$ \\
\hline & $V^{\prime}{ }^{\prime} N^{\prime} \mathrm{CO}_{2}$ at $A T$ & $\uparrow$ & $\uparrow \uparrow$ & $\uparrow \uparrow$ \\
\hline & $\mathrm{P}_{\mathrm{ET}} \mathrm{CO}_{2}$ & $\downarrow$ & $\downarrow \downarrow$ & $\downarrow \downarrow$ \\
\hline & $\mathrm{SaO}_{2}$ & $\downarrow$ & $\downarrow \downarrow$ & $\downarrow \downarrow$ \\
\hline & $\mathrm{Pa-ETCO} 2$ & $\uparrow$ & $\uparrow \uparrow$ & $\uparrow \uparrow$ \\
\hline & $\mathrm{P}_{\mathrm{A}-\mathrm{a}} \mathrm{O}_{2}$ & $\uparrow$ & $\uparrow \uparrow$ & $\uparrow \uparrow$ \\
\hline & $V_{D} / V_{T}$ & $\uparrow$ & $\uparrow \uparrow$ & $\uparrow \uparrow$ \\
\hline
\end{tabular}

CPET, cardiopulmonary exercise testing; $P A H$, pulmonary arterial hypertension; CTEPH, chronic thromboembolic pulmonary hypertension; PVOD; pulmonary veno-occlusive disease; $V^{\prime} \mathrm{O}_{2}$, oxygen consumption; $A T$, ventilator/anaerobic threshold; WR, work rate; $\mathrm{O}_{2}$ pulse, peak $\mathrm{V}^{\prime} \mathrm{O}_{2}$ to heart rate ratio at peak exercise; $V^{\prime} E$, minute ventilation; $V^{\prime} E N V^{\prime} \mathrm{CO}_{2}$, ratio of minute ventilation to carbon dioxide production $\left(\mathrm{V}^{\prime} \mathrm{CO}_{2}\right) ; \mathrm{PETCO}_{2}$, end-tidal pressure of carbon dioxide; $\mathrm{SaO}_{2}$, arterial oxygen saturation; $P A-a O_{2}$, alveolar-arterial oxygen pressure gradient at peak exercise; $\mathrm{Pa}-\mathrm{ETCO}_{2}$, arterial to end-tidal carbon dioxide pressure gradient at peak exercise; VDNT, physiologic dead space fraction as ratio of dead space (VD) to tidal volume (VT) at peak exercise.

augmented ventilatory drive cannot alone explain the origin of the multifaceted symptom of dyspnea, and other contributions stemming from respiratory and skeletal muscle (dys)function, as well as psychological and emotional status may come into play. Recently, abnormalities of breathing mechanics have been pointed out in some PAH and CTEPH patients during exercise (Richter et al., 2012; Laveneziana et al., 2013b, 2015; Dorneles et al., 2019; Boucly et al., 2020; Figure 5) and are likely to precipitate exertional dyspnea in these two populations (Laveneziana et al., 2013b, 2015; Dorneles et al., 2019; Boucly et al., 2020; Figure 4).

Now, what kind of abnormalities of breathing mechanics have been observed in PAH and CTEPH patients that can explain, at least in part, dyspnea generated during exertion and during laboratory-based CPET? Without giving to much of details on the underlying mechanisms of the anomalies of breathing mechanics encountered during CPET in PAH and CTEPH patients (which goes outside the scope of this review), we can say that some features are the development of EFL and dynamic lung hyperinflation (indicated by an increased end- expiratory lung volume, i.e., EELV that is mirrored by a decrease of the same amount/proportion in IC on exertion) with concurrent limitation of $\mathrm{V}_{\mathrm{T}}$ expansion and attainment of a critical IRV in at least $60 \%$ of these patients (Richter et al., 2012; Laveneziana et al., 2013b, 2015; Dorneles et al., 2019; Boucly et al., 2020; Figure 5). Of course some considerations must be made here: EFL is most of the time not present at rest and resting IC is preserved (Laveneziana et al., 2013b, 2015; Boucly et al., 2020), even in CTEPH pre and post-pulmonary endarterectomy (Richter et al., 2017); what is evident in $60 \%$ of these patients (PAH and CTEPH) is a reduction of the forced expiratory flow at low lung volumes $\left(\mathrm{FEF}_{75 \%}\right)$ where $\mathrm{V}_{\mathrm{T}}$ occurs; this predisposes to dynamic decrease in IC and limitation of $\mathrm{V}_{\mathrm{T}}$ expansion with concomitant attainment of a critical IRV in some of these $\mathrm{PAH}$ and CTEPH patients, as 

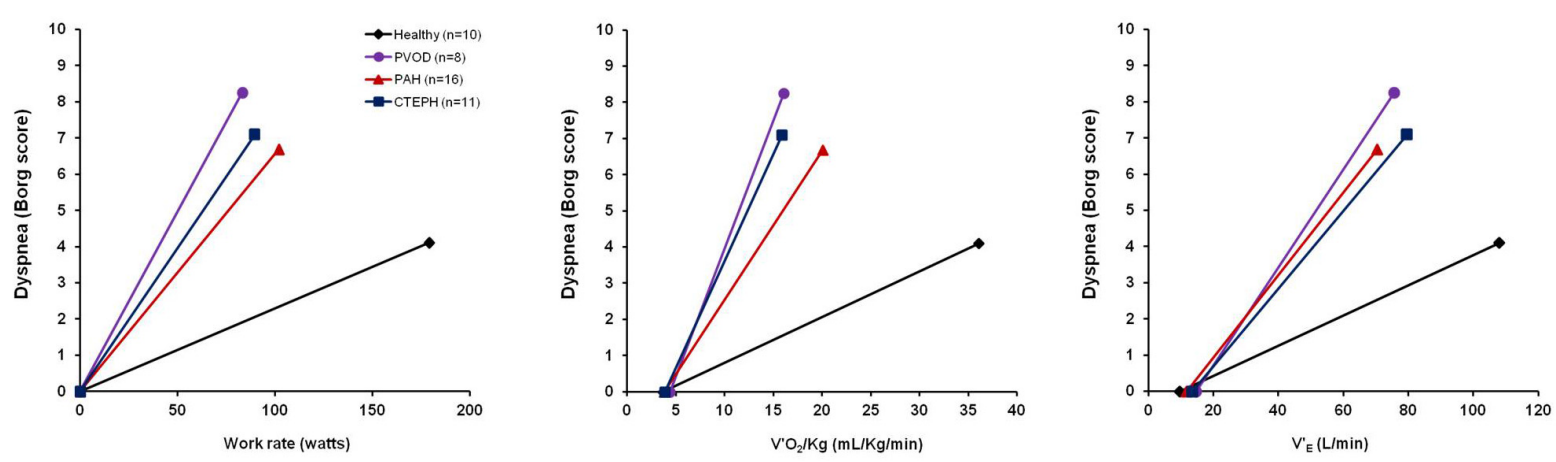

FIGURE 4 | Exertional dyspnea intensity as measured by Borg score is displayed in response to increasing work rate (left panel), increasing oxygen consumption $\left(\mathrm{V}_{1} \mathrm{O}_{2} / \mathrm{Kg}\right.$, mid panel) and increasing minute ventilation $\left(\mathrm{V}_{\mathrm{E}}\right.$, right panel) during symptom limited cardiopulmonary exercise testing in 10 healthy subjects (black line and rhomboid), 8 patients with pulmonary veno-occlusive disease (PVOD) (violet line and circles), 16 patients with pulmonary arterial hypertension (PAH) (red line and triangles), 11 patients with chronic thromboembolic pulmonary hypertension (CTEPH) (blue line and squares). The origin of the data provided in Figure 4 is from Laveneziana et al. (2013b, 2014a, 2015), Boucly et al. (2020) and Weatherald et al. (2020).

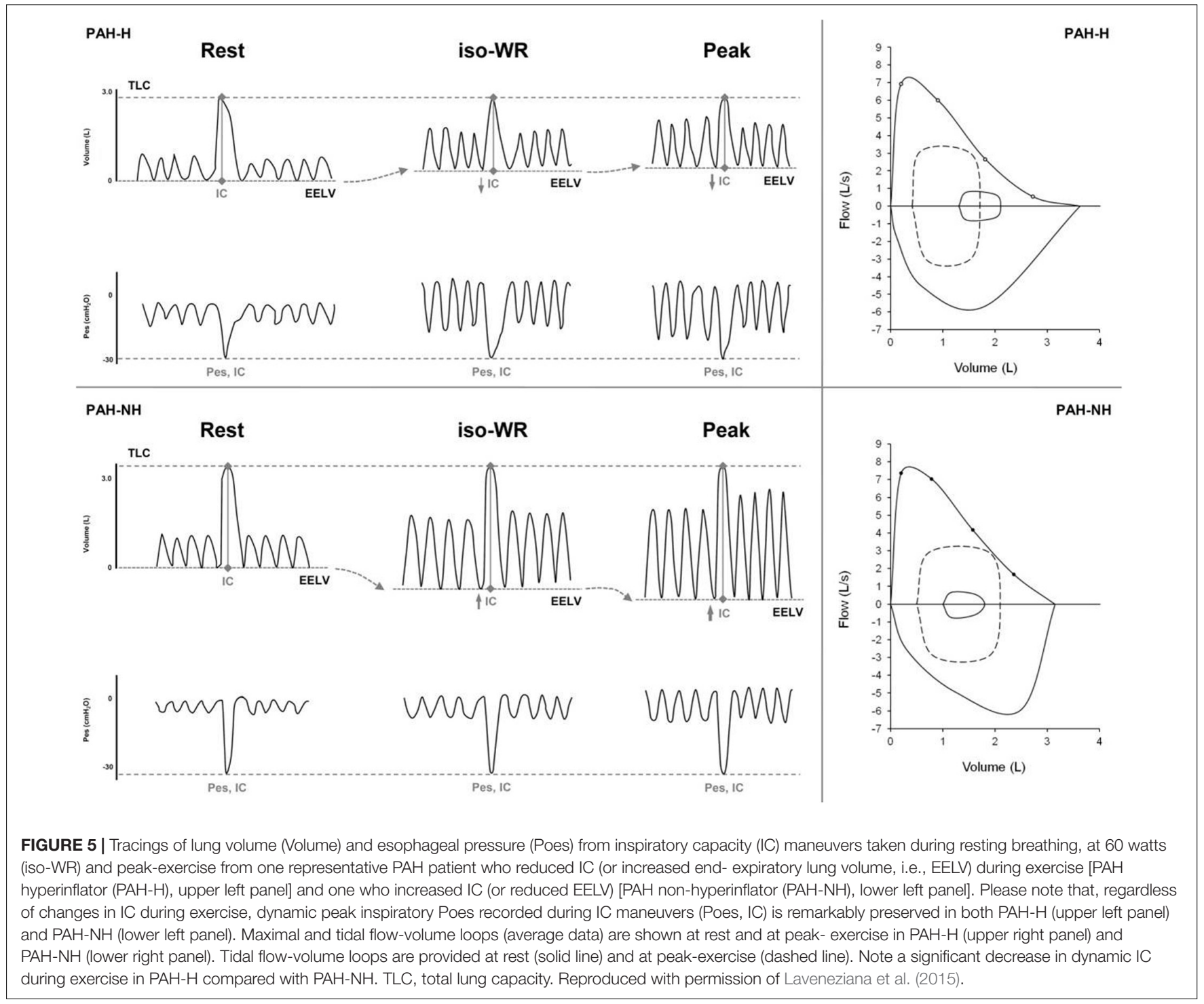



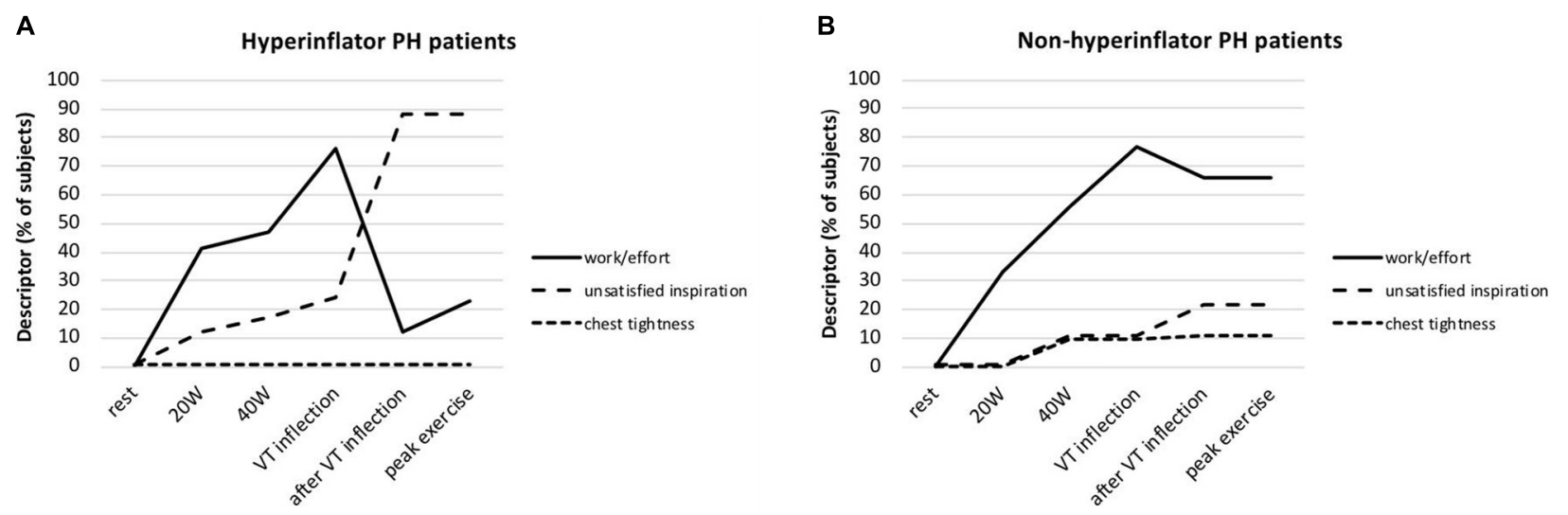

FIGURE 6 | (A) Selection frequency of the three descriptor phrases evaluated during symptom-limited incremental cycle exercise in patients with pulmonary hypertension (PH) who hyperinflate (Hyperinflators) during exercise: increased work/effort, unsatisfied inspiration, and chest tightness. Data are presented as mean at rest, at 20W (iso-WR 1), at $40 \mathrm{~W}$ (iso-WR 2), at the tidal volume (VT) inflection point, after the VT inflection point and at peak exercise. (B) Selection frequency of the three descriptor phrases evaluated during symptom-limited incremental cycle exercise in patients with pulmonary hypertension (PH) who deflate (Non-hyperinflators) during exercise: increased work/effort, unsatisfied inspiration, and chest tightness. Data are presented as mean at rest, at 20W (iso-WR 1), at 40 W (iso-WR 2), at the tidal volume (VT) inflection point, after the VT inflection point and at peak exercise. Reproduced with permission of Boucly et al. (2020).

it may occur in some patients with asthma (Laveneziana et al., 2006, 2013a), chronic obstructive pulmonary disease (COPD) (Laveneziana et al., 2011, 2014b; Guenette et al., 2012; Soumagne et al., 2016) and chronic heart failure (CHF) (Laveneziana et al., 2009; Laveneziana and Di Paolo, 2019; Smith et al., 2019). The sensory consequence of this is the escalation of dyspnea intensity and the transition in its qualitative description from "work/effort" to "unsatisfied inspiration" (Figure 6), as is the case in some asthmatics (Laveneziana et al., 2006, 2013a), and COPD patients (Laveneziana et al., 2011, 2014b; Guenette et al., 2012; Soumagne et al., 2016).

Of note, these particular PAH and CTEPH patients present also with a high level of anxiety which is frequently associated with dyspnea on exertion (Boucly et al., 2020). It should be noted here that $40 \%$ of these PAH and CTEPH patients do not manifest decrease in IC (meaning that they deflate normally during exercise), nor limitation of $\mathrm{V}_{\mathrm{T}}$ expansion nor attainment of a critical IRV during CPET (Laveneziana et al., 2013b, 2015; Boucly et al., 2020). Dyspnea intensity in this group of $\mathrm{PAH}$ and CTEPH is less important than in the other group previously described (Laveneziana et al., 2013b, 2015; Boucly et al., 2020) and its qualitative description remains predominantly the sense of breathing "work/effort" (Laveneziana et al., 2013b, 2015; Boucly et al., 2020; Figure 6), as it occurs in healthy subjects on exertion (Laveneziana et al., 2013b, 2014b).

Another important point to bring to reader attention here is whether the dynamic decrease in IC observed during CPET in some PAH and CTEPH patients is truly reflective of dynamic lung hyperinflation or could be related to a dysfunction of inspiratory muscle (weakness or fatigue). The occurrence of fatigue or the overt presence of weakness of inspiratory muscle in $\mathrm{PAH}$ patients have been questioned by two studies from Laveneziana et al. (2013b, 2015; Figure 5) that have assessed the reliability of IC maneuvers in $\mathrm{PH}$ patients by (1) comparing inspiratory esophageal pressure (Poes) values during IC manoeuvers, (2) comparing sniff-Poes values pre- vs. post-exercise in $\mathrm{PH}$ patients and (3) comparing TLC pre- vs post-maximal CPET. These studies clearly pointed out that (1) Poes values measured during IC manoeuvers were remarkably preserved during exercise and were independent of exercise intensity and $\mathrm{V}_{\mathrm{E}}^{\prime}$ in $\mathrm{PAH}$ (Laveneziana et al., 2015), (2) sniff-Poes values were identical prevs. post-exercise in $\mathrm{PH}$ patients (Laveneziana et al., 2015) and (3) TLC pre CPET was superimposed to TLC immediately postexercise in PH patients (Laveneziana et al., 2013b, 2015). Taken together these findings prove that IC maneuvers are reliable (Laveneziana et al., 2013b, 2015) and that inspiratory muscle dysfunction is unlikely to manifest, at least in these stable PAH patients (Laveneziana et al., 2013b, 2015; Figure 5).

\section{PROGNOSTIC UTILITY OF CPET}

There is good evidence that CPET variables can be used to measure disease severity and are predictive of survival and time to clinical worsening in PAH and CTEPH patients as well as potential treatment targets for $\mathrm{PAH}$ patients, with objectives of obtaining peak $\mathrm{V}^{\prime} \mathrm{O}_{2}>15 \mathrm{~mL} \cdot \mathrm{min}^{-1} \cdot \mathrm{kg}^{-1}$ or $>65 \%$ predicted and a $\mathrm{V}^{\prime}{ }_{\mathrm{E}} / \mathrm{V}^{\prime} \mathrm{CO}_{2}$ slope of $<36$ (Galie et al., 2015; PuenteMaestu et al., 2016). $\mathrm{PAH}$ patients with a peak $\mathrm{V}^{\prime} \mathrm{O}_{2}$ less than $11 \mathrm{~mL} \cdot \mathrm{min}^{-1} \cdot \mathrm{kg}^{-1}$ or a $\mathrm{V}_{\mathrm{E}}^{\prime} / \mathrm{V}^{\prime} \mathrm{CO}_{2}$ slope $\geq 45$ are considered high risk with an estimated 1-year mortality of $>10 \%$ according to European Society of Cardiology/European Respiratory Society guidelines (Galie et al., 2015). Peak V'O ${ }_{2}$ and $\mathrm{V}^{\prime}{ }_{\mathrm{E}} / \mathrm{V}^{\prime} \mathrm{CO}_{2}$ have been associated with survival in several studies including PAH and CTEPH patients (Wensel et al., 2002; Deboeck et al., 2012; Schwaiblmair et al., 2012; Groepenhoff et al., 2013). Wensel et al. (2013) demonstrated that peak $\mathrm{V}^{\prime} \mathrm{O}_{2}$ provides additional prognostic value to resting haemodynamics in patients with $\mathrm{PAH}$. Those with a low $\mathrm{V}^{\prime} \mathrm{O}_{2}(<46.3 \%$ predicted $)$ and PVR $>16$ Wood units had a particularly dismal prognosis, while patients with 
peak $\mathrm{V}^{\prime} \mathrm{O}_{2} \geq 46.3 \%$ predicted and a PVR $<11.6$ Wood units had $>90 \%$ 5-year survival. Echocardiographic assessment of RV function in combination with CPET may provide incremental prognostic utility. Badagliacca and colleagues found that RV fractional area change on echocardiogram, in conjunction with the $\mathrm{O}_{2}$ pulse from CPET, which reflect RV function and stroke volume, were independent predictors of outcome in patients with idiopathic PAH (Badagliacca et al., 2016). Patients with RV fractional area change $>26.5 \%$ and an $\mathrm{O}_{2}$ pulse $>8.0$ mL.beat $^{-1}$ had excellent long-term survival, while PAH patients with RV fractional area change $<36.5 \%$ and an $\mathrm{O}_{2}$ pulse $<8.0$ mL.beat $^{-1}$ had significantly worse survival.

Others have also demonstrated that while $\mathrm{V}_{\mathrm{E}}^{\prime} / \mathrm{V}^{\prime} \mathrm{CO}_{2}$ slope as well as $\mathrm{V}^{\prime}{ }_{\mathrm{E}} / \mathrm{V}^{\prime} \mathrm{CO}_{2}$ peak were associated with survival, once multivariate regression was performed, only $\Delta \mathrm{O}_{2}$ pulse added prognostic value (Groepenhoff et al., 2008). Hemodynamic variables such as PVR and those that reflect right ventricular function (cardiac output, stroke volume, right atrial pressure) are also important predictors of prognosis in PAH (Saggar and Sitbon, 2012; Weatherald et al., 2018a,b; Benza et al., 2019). Wensel et al. evaluated the prognostic value of combining CPETderived variables with haemodynamic data from RHC (Wensel et al., 2013) they assessed several CPET variables, including $\mathrm{V}_{\mathrm{E}} / \mathrm{V}^{\prime} \mathrm{CO}_{2}$, and found that only peak $\mathrm{VO}_{2}, \mathrm{PVR}$, and $\mathrm{HR}$ change during exercise were independently associated with survival. Similarly, another study by Badagliacca et al., found that the only

\section{REFERENCES}

Agostoni, P., Apostolo, A., Cattadori, G., Salvioni, E., Berna, G., Antonioli, L., et al. (2010). Effects of beta-blockers on ventilation efficiency in heart failure. Am. Heart. J 159, 1067-1073.

Agostoni, P., Guazzi, M., Bussotti, M., De Vita, S., and Palermo, P. (2002). Carvedilol reduces the inappropriate increase of ventilation during exercise in heart failure patients. Chest 122, 2062-2067. doi: 10.1378/chest.122.6.2062

Agusti, A. G. N., Anderson, D., Roca, J., Whipp, B., Casburi, R., and Cotes, J. (1997). Clinical exercise testing with reference to lung diseases: indications, standardization and interpretation strategies. ERS Task Force on Standardization of Clinical Exercise Testing. European Respiratory Society. Eur. Respir. J. 10, 2662-2689. doi: 10.1183/09031936.97.10112662

American Thoracic Society (2003). ATS/ACCP Statement on cardiopulmonary exercise testing. Am. J. Respir. Crit. Care Med. 167, 211-277. doi: 10.1164/rccm. 167.2.211

ATS/ACCP (2003). Statement on cardiopulmonary exercise testing. Am. J. Respir. Crit. Care Med. 167, 211-277.

Badagliacca, R., Papa, S., Poscia, R., Valli, G., Pezzuto, B., Manzi, G., et al. (2019). The added value of cardiopulmonary exercise testing in the followup of pulmonary arterial hypertension. J. Heart Lung Transpl. 38, 306-314. doi: 10.1016/j.healun.2018.11.015

Badagliacca, R., Papa, S., Valli, G., Pezzuto, B., Poscia, R., Manzi, G., et al. (2016). Echocardiography combined with cardiopulmonary exercise testing for the prediction of outcome in idiopathic pulmonary arterial hypertension. Chest 150, 1313-1322. doi: 10.1016/j.chest.2016.07.036

Bauer, R., Dehnert, C., Schoene, P., Filusch, A., Bartsch, P., Borst, M. M., et al. (2007). Skeletal muscle dysfunction in patients with idiopathic pulmonary arterial hypertension. Respir. Med. 101, 2366-2369.

Benza, R. L., Gomberg-Maitland, M., Elliott, C. G., Farber, H. W., Foreman, A. J., Frost, A. E., et al. (2019). Predicting survival in patients with pulmonary arterial hypertension: the REVEAL risk score calculator 2.0 and comparison with ESC/ERS-based risk assessment strategies. Chest 156, 323-337.

Boucly, A., Morelot-Panzini, C., Garcia, G., Weatherald, J., Jais, X., Savale, L., et al. (2020). Intensity and quality of exertional dyspnoea in patients with stable useful CPET parameter independently associated with future clinical worsening was peak $\mathrm{VO}_{2}$, with $\mathrm{V}_{\mathrm{E}} / \mathrm{V}^{\prime} \mathrm{CO}_{2}$ not adding additional prognostic information (Badagliacca et al., 2019).

\section{CONCLUSION}

Cardiopulmonary exercise testing (CPET) is of great interest and utility for clinicians dealing with Pulmonary Hypertension (PH) in several ways such as: helping orienting diagnosis, evaluating exercise intolerance and its underpinning mechanisms, accurately assessing exertional dyspnea and unmasking its underlying often non straightforward mechanisms, generating prognostic indicators. Pathophysiologic anomalies in $\mathrm{PH}$ can range from reduced cardiac output and aerobic capacity, to inefficient ventilation, dyspnea, dynamic hyperinflation and locomotor muscle dysfunction. CPET can magnify the PHrelated pathophysiologic anomalies and has a major role in the management of $\mathrm{PH}$ patients.

\section{AUTHOR CONTRIBUTIONS}

PL and JW equally contributed to the writing and revision of the manuscript. Both authors contributed to the article and approved the submitted version.

pulmonary hypertension. Eur. Respir. J. 55:1802108. doi: 10.1183/13993003. 02108-2018

D’Alonzo, G. E., Gianotti, L. A., Pohil, R. L., Reagle, R. R., DuRee, S. L., and Dantzker, D. R. (1987). Comparison of progressive exercise performance of normal subjects and patients with primary pulmonary hypertension. Chest 92 , 57-62. doi: 10.1378/chest.92.1.57

Deboeck, G., Niset, G., Lamotte, M., Vachiery, J. L., and Naeije, R. (2004). Exercise testing in pulmonary arterial hypertension and in chronic heart failure. Eur. Respir. J. 23, 747-751. doi: 10.1183/09031936.04.00111904

Deboeck, G., Scoditti, C., Huez, S., Vachiery, J. L., Lamotte, M., Sharples, L., et al. (2012). Exercise testing to predict outcome in idiopathic versus associated pulmonary arterial hypertension. Eur. Respir. J. 40, 1410-1419.

Dimopoulos, S., Tzanis, G., Manetos, C., Tasoulis, A., Mpouchla, A., Tseliou, E., et al. (2013). Peripheral muscle microcirculatory alterations in patients with pulmonary arterial hypertension: a pilot study. Respir. Care 58, 2134-2141. doi: 10.4187/respcare.02113

Dorneles, R. G., Plachi, F., Gass, R., Toniazzo, V. T., Thome, P., Sanches, P. R., et al. (2019). Sensory consequences of critical inspiratory constraints during exercise in pulmonary arterial hypertension. Respir. Physiol. Neurobiol. 261, 40-47. doi: 10.1016/j.resp.2019.01.002

Duscha, B. D., Robbins, J. L., Jones, W. S., Kraus, W. E., Lye, R. J., Sanders, J. M., et al. (2011). Angiogenesis in skeletal muscle precede improvements in peak oxygen uptake in peripheral artery disease patients. Arterioscler. Thromb. Vasc. Biol. 31, 2742-2748. doi: 10.1161/atvbaha.111.230441

Ehlken, N., Lichtblau, M., Klose, H., Weidenhammer, J., Fischer, C., Nechwatal, R., et al. (2016). Exercise training improves peak oxygen consumption and haemodynamics in patients with severe pulmonary arterial hypertension and inoperable chronic thrombo-embolic pulmonary hypertension: a prospective, randomized, controlled trial. Eur. Heart J. 37, 35-44. doi: 10.1093/eurheartj/ ehv337

Esposito, F., Mathieu-Costello, O., Shabetai, R., Wagner, P. D., and Richardson, R. S. (2010). Limited maximal exercise capacity in patients with chronic heart failure: partitioning the contributors. J. Am. Coll. Cardiol. 55, 1945-1954.

Esposito, F., Reese, V., Shabetai, R., Wagner, P. D., and Richardson, R. S. (2011). Isolated quadriceps training increases maximal exercise capacity in chronic 
heart failure: the role of skeletal muscle convective and diffusive oxygen transport. J. Am. Coll. Cardiol. 58, 1353-1362. doi: 10.1016/j.jacc.2011.06.025

Farina, S., Bruno, N., Agalbato, C., Contini, M., Cassandro, R., Elia, D., et al. (2018). Physiological insights of exercise hyperventilation in arterial and chronic thromboembolic pulmonary hypertension. Int. J. Cardiol. 259, 178-182. doi: 10.1016/j.ijcard.2017.11.023

Galie, N., Humbert, M., Vachiery, J. L., Gibbs, S., Lang, I., Torbicki, A., et al. (2015). ESC/ERS guidelines for the diagnosis and treatment of pulmonary hypertension: the joint task force for the diagnosis and treatment of pulmonary hypertension of the european society of cardiology (ESC) and the european respiratory society (ERS): endorsed by: association for european paediatric and congenital cardiology (AEPC), international society for heart and lung transplantation (ISHLT). Eur. Respir. J. 46, 903-975. doi: 10.1183/13993003. 01032-2015

Galie, N., Rubin, L., Hoeper, M., Jansa, P., Al-Hiti, H., Meyer, G., et al. (2008). Treatment of patients with mildly symptomatic pulmonary arterial hypertension with bosentan (EARLY study): a double-blind, randomised controlled trial. Lancet 371, 2093-2100. doi: 10.1016/s0140-6736(08)60919-8

Godinas, L., Sattler, C., Lau, E. M., Jais, X., Taniguchi, Y., Jevnikar, M., et al. (2017). Dead-space ventilation is linked to exercise capacity and survival in distal chronic thromboembolic pulmonary hypertension. J. Heart Lung Transpl. 36, 1234-1242. doi: 10.1016/j.healun.2017.05.024

Groepenhoff, H., Vonk-Noordegraaf, A., Boonstra, A., Spreeuwenberg, M. D., Postmus, P. E., and Bogaard, H. J. (2008). Exercise testing to estimate survival in pulmonary hypertension. Med. Sci. Sports Exerc. 40, 1725-1732. doi: 10.1249/ mss.0b013e31817c92c0

Groepenhoff, H., Vonk-Noordegraaf, A., van de Veerdonk, M. C., Boonstra, A., Westerhof, N., and Bogaard, H. J. (2013). Prognostic relevance of changes in exercise test variables in pulmonary arterial hypertension. PLOS ONE 8:e72013. doi: 10.1371/journal.pone.0072013

Guenette, J. A., Webb, K. A., and O'Donnell, D. E. (2012). Does dynamic hyperinflation contribute to dyspnoea during exercise in patients with COPD? Eur. Respir. J. 40, 322-329. doi: 10.1183/09031936.00157711

Hasler, E. D., Muller-Mottet, S., Furian, M., Saxer, S., Huber, L. C., Maggiorini, M., et al. (2016). Pressure-flow during exercise catheterization predicts survival in pulmonary hypertension. Chest 150, 57-67. doi: 10.1016/j.chest.2016.02.634

Hoeper, M. M., Pletz, M. W., Golpon, H., and Welte, T. (2007). Prognostic value of blood gas analyses in patients with idiopathic pulmonary arterial hypertension. Eur. Respir. J. 29, 944-950. doi: 10.1183/09031936.00134506

Huckstepp, R. T. R., Cardoza, K. P., Henderson, L. E., and Feldman, J. L. (2018). Distinct parafacial regions in control of breathing in adult rats. PLOS ONE 13:e0201485. doi: 10.1371/journal.pone.0201485

Humbert, M., Guignabert, C., Bonnet, S., Dorfmuller, P., Klinger, J. R., Nicolls, M. R., et al. (2019). Pathology and pathobiology of pulmonary hypertension: state of the art and research perspectives. Eur. Respir. J. 53, 1801887. doi: 10.1183/13993003.01887-2018

Humbert, M., Yaici, A., de Groote, P., Montani, D., Sitbon, O., Launay, D., et al. (2011). Screening for pulmonary arterial hypertension in patients with systemic sclerosis: clinical characteristics at diagnosis and long-term survival. Arthritis Rheum. 63, 3522-3530. doi: 10.1002/art.30541

Johnson, B. D., Weisman, I. M., Zeballos, R. J., and Beck, K. C. (1999). Emerging concepts in the evaluation of ventilatory limitation during exercise: the exercise tidal flow-volume loop. Chest 116, 488-503. doi: 10.1378/chest.116.2.488

Kovacs, G., Berghold, A., Scheidl, S., and Olschewski, H. (2009). Pulmonary arterial pressure during rest and exercise in healthy subjects: a systematic review. Eur. Respir. J. 34, 888-894. doi: 10.1183/09031936.00145608

Kovacs, G., Herve, P., Barbera, J. A., Chaouat, A., Chemla, D., Condliffe, R., et al. (2017). An official European respiratory society statement: pulmonary haemodynamics during exercise. Eur. Respir. J. 50, 1700578. doi: 10.1183/ 13993003.00578-2017

Lau, E. M., Humbert, M., and Celermajer, D. S. (2015). Early detection of pulmonary arterial hypertension. Nat. Rev. Cardiol. 12, 143-155.

Laveneziana, P., Agostoni, P., Mignatti, A., Mushtaq, S., Colombo, P., Sims, D., et al. (2010). Effect of acute beta-blocker withholding on ventilatory efficiency in patients with advanced chronic heart failure. J. Card. Fail. 16, 548-555. doi: 10.1016/j.cardfail.2010.02.006

Laveneziana, P., Bruni, G. I., Presi, I., Stendardi, L., Duranti, R., and Scano, G. (2013a). Tidal volume inflection and its sensory consequences during exercise in patients with stable asthma. Respir. Physiol. Neurobiol. 185, 374-379. doi: 10.1016/j.resp.2012.08.026

Laveneziana, P., Garcia, G., Joureau, B., Nicolas-Jilwan, F., Brahimi, T., Laviolette, L., et al. (2013b). Dynamic respiratory mechanics and exertional dyspnoea in pulmonary arterial hypertension. Eur. Respir. J. 41, 578-587. doi: 10.1183/ 09031936.00223611

Laveneziana, P., and Di Paolo, M. (2019). Exploring cardiopulmonary interactions during constant-workload submaximal cycle exercise in COPD patients. J. Appl. Physiol. (1985) 127, 688-690. doi: 10.1152/japplphysiol.00526.2019

Laveneziana, P., Humbert, M., Godinas, L., Joureau, B., Malrin, R., Straus, C., et al. (2015). Inspiratory muscle function, dynamic hyperinflation and exertional dyspnoea in pulmonary arterial hypertension. Eur. Respir. J. 45, 1495-1498. doi: 10.1183/09031936.00153214

Laveneziana, P., Lotti, P., Coli, C., Binazzi, B., Chiti, L., Stendardi, L., et al. (2006). Mechanisms of dyspnoea and its language in patients with asthma. Eur. Respir. J. 27, 742-747. doi: 10.1183/09031936.06.00080505

Laveneziana, P., Montani, D., Dorfmuller, P., Girerd, B., Sitbon, O., Jais, X., et al. (2014a). Mechanisms of exertional dyspnoea in pulmonary veno-occlusive disease with EIF2AK4 mutations. Eur. Respir. J. 44, 1069-1072. doi: 10.1183/ 09031936.00088914

Laveneziana, P., Webb, K. A., Wadell, K., Neder, J. A., and O'Donnell, D. E. (2014b). Does expiratory muscle activity influence dynamic hyperinflation and exertional dyspnea in COPD? Respir. Physiol. Neurobiol. 199, 24-33. doi: 10. 1016/j.resp.2014.04.005

Laveneziana, P., O’Donnell, D. E., Ofir, D., Agostoni, P., Padeletti, L., Ricciardi, G., et al. (2009). Effect of biventricular pacing on ventilatory and perceptual responses to exercise in patients with stable chronic heart failure. J. Appl. Physiol. (1985) 106, 1574-1583. doi: 10.1152/japplphysiol.90744.2008

Laveneziana, P., Webb, K. A., Ora, J., Wadell, K., and O'Donnell, D. E. (2011). Evolution of dyspnea during exercise in chronic obstructive pulmonary disease: impact of critical volume constraints. Am. J. Respir. Crit. Care Med. 184, 1367-1373. doi: 10.1164/rccm.201106-1128oc

Laviolette, L., and Laveneziana, P. (2014). Dyspnoea: a multidimensional and multidisciplinary approach. Eur. Respir. J. 43, 1750-1762. doi: 10.1183/ 09031936.00092613

Mainguy, V., Maltais, F., Saey, D., Gagnon, P., Martel, S., Simon, M., et al. (2010). Peripheral muscle dysfunction in idiopathic pulmonary arterial hypertension. Thorax 65, 113-117. doi: 10.1136/thx.2009.117168

Manders, E., Bonta, P. I., Kloek, J. J., Symersky, P., Bogaard, H. J., Hooijman, P. E., et al. (2016). Reduced force of diaphragm muscle fibers in patients with chronic thromboembolic pulmonary hypertension. Am. J. Physiol. Lung. Cell Mol. Physiol. 311, L20-L28.

Mereles, D., Ehlken, N., Kreuscher, S., Ghofrani, S., Hoeper, M. M., Halank, M., et al. (2006). Exercise and respiratory training improve exercise capacity and quality of life in patients with severe chronic pulmonary hypertension. Circulation 114, 1482-1489. doi: 10.1161/circulationaha.106.618397

Naeije, R., and Badagliacca, R. (2017). The overloaded right heart and ventricular interdependence. Cardiovasc. Res. 113, 1474-1485. doi: 10.1093/cvr/cvx160

Naeije, R., and van de Borne, P. (2009). Clinical relevance of autonomic nervous system disturbances in pulmonary arterial hypertension. Eur. Respir. J. 34, 792-794. doi: 10.1183/09031936.00091609

Nootens, M., Wolfkiel, C. J., Chomka, E. V., and Rich, S. (1995). Understanding right and left ventricular systolic function and interactions at rest and with exercise in primary pulmonary hypertension. Am. J. Cardiol. 75, 374-377. doi: 10.1016/s0002-9149(99)80557-8

Oudiz, R. J., Midde, R., Hovenesyan, A., Sun, X. G., Roveran, G., Hansen, J. E., et al. (2010). Usefulness of right-to-left shunting and poor exercise gas exchange for predicting prognosis in patients with pulmonary arterial hypertension. Am. J. Cardiol. 105, 1186-1191. doi: 10.1016/j.amjcard.2009.12.024

Palange, P., Ward, S. A., Carlsen, K. H., Casaburi, R., Gallagher, C. G., Gosselink, R., et al. (2007). Recommendations on the use of exercise testing in clinical practice. Eur. Respir. J. 29, 185-209.

Palange, P. L., Neder, J. A., and Ward, S. A. (2018). Clinical Exercise Testing. ERS Monograph. Sheffield: European Respiratory Society.

Potus, F., Malenfant, S., Graydon, C., Mainguy, V., Tremblay, E., Breuils-Bonnet, S., et al. (2014). Impaired angiogenesis and peripheral muscle microcirculation loss contribute to exercise intolerance in pulmonary arterial hypertension. Am. J. Respir. Crit. Care Med. 190, 318-328. 
Puente-Maestu, L., García de Pedro, J., Troosters, T., Neder, J. A., Puhan, M. A., Benedetti, P. A., et al. (eds) (2018). Clinical Exercise Testing. Sheffield: European Respiratory Society, 88-106. doi: 110.1183/2312508X.10011217

Puente-Maestu, L., Palange, P., Casaburi, R., Laveneziana, P., Maltais, F., Neder, J. A., et al. (2016). Use of exercise testing in the evaluation of interventional efficacy: an official ERS statement. Eur. Respir. J. 47, 429-460. doi: 10.1183/ 13993003.00745-2015

Radtke, T., Crook, S., Kaltsakas, G., Louvaris, Z., Berton, D., Urquhart, D. S., et al. (2019). ERS statement on standardisation of cardiopulmonary exercise testing in chronic lung diseases. Eur. Respir. Rev. 28.

Richter, M. J., Gall, H., Wittkamper, G., Seeger, W., Mayer, E., Ghofrani, H. A., et al. (2017). Inspiratory capacity is not altered in operable chronic thromboembolic pulmonary hypertension. Pulmon. Circ. 7, 543-546. doi: 10. $1177 / 2045893217709763$

Richter, M. J., Voswinckel, R., Tiede, H., Schulz, R., Tanislav, C., Feustel, A., et al. (2012). Dynamic hyperinflation during exercise in patients with precapillary pulmonary hypertension. Respir. Med. 106, 308-313. doi: 10.1016/j.rmed.2011. 10.018

Riley, M. S., Porszasz, J., Engelen, M. P., Brundage, B. H., and Wasserman, K. (2000). Gas exchange responses to continuous incremental cycle ergometry exercise in primary pulmonary hypertension in humans. Eur. J. Appl. Physiol. 83, 63-70. doi: 10.1007/s004210000240

Saggar, R., and Sitbon, O. (2012). Hemodynamics in pulmonary arterial hypertension: current and future perspectives. Am. J. Cardiol. 110, 9S-15S.

Scheidl, S. J., Englisch, C., Kovacs, G., Reichenberger, F., Schulz, R., Breithecker, A., et al. (2012). Diagnosis of CTEPH versus IPAH using capillary to end-tidal carbon dioxide gradients. Eur. Respir. J. 39, 119-124. doi: 10.1183/09031936. 00109710

Schwaiblmair, M., Faul, C., von Scheidt, W., and Berghaus, T. M. (2012). Ventilatory efficiency testing as prognostic value in patients with pulmonary hypertension. BMC Pulmon. Med. 12:23. doi: 10.1186/1471-2466-12-23

Simonneau, G., Montani, D., Celermajer, D. S., Denton, C. P., Gatzoulis, M. A., Krowka, M., et al. (2019). Haemodynamic definitions and updated clinical classification of pulmonary hypertension. Eur. Respir. J. 53, 1801913. doi: 10. 1183/13993003.01913-2018

Smith, J. R., Johnson, B. D., and Olson, T. P. (2019). Impaired central hemodynamics in chronic obstructive pulmonary disease during submaximal exercise. J. Appl. Physiol. (1985) 127, 691-697. doi: 10.1152/japplphysiol.00877. 2018

Soumagne, T., Laveneziana, P., Veil-Picard, M., Guillien, A., Claude, F., Puyraveau, M., et al. (2016). Asymptomatic subjects with airway obstruction have significant impairment at exercise. Thorax 71, 804-811. doi: 10.1136/thoraxjnl2015-207953

Sun, X. G., Hansen, J. E., Garatachea, N., Storer, T. W., and Wasserman, K. (2002). Ventilatory efficiency during exercise in healthy subjects. Am. J. Respir. Crit. Care Med. 166, 1443-1448. doi: 10.1164/rccm.2202033

Sun, X. G., Hansen, J. E., Oudiz, R. J., and Wasserman, K. (2001). Exercise pathophysiology in patients with primary pulmonary hypertension. Circulation 104, 429-435. doi: 10.1161/hc2901.093198

Tolle, J., Waxman, A., and Systrom, D. (2008). Impaired systemic oxygen extraction at maximum exercise in pulmonary hypertension. Med. Sci. Sports Exerc. 40, 3-8. doi: 10.1249/mss.0b013e318159d1b8

Valli, G., Palange, P., Badagliacca, R., Papa, S., Poscia, R., and Vizza, C. D. (2019). Exercise energy expenditure in patients with idiopathic pulmonary arterial hypertension: Impact on clinical severity and survival. Respir. Physiol. Neurobiol. 264, 33-39. doi: 10.1016/j.resp.2019.04.003

Velez-Roa, S., Ciarka, A., Najem, B., Vachiery, J. L., Naeije, R., and van de Borne, P. (2004). Increased sympathetic nerve activity in pulmonary artery hypertension. Circulation 110, 1308-1312. doi: 10.1161/01.cir.0000140724. 90898.d3

Wasserman, K., Whipp, B. J., Koyal, S. N., and Cleary, M. G. (1975). Effect of carotid body resection on ventilatory and acid-base control during exercise. J. Appl. Physiol. 39, 354-358. doi: 10.1152/jappl.1975.39.3.354

Weatherald, J., Boucly, A., Chemla, D., Savale, L., Peng, M., Jevnikar, M., et al. (2018a). Prognostic value of follow-up hemodynamic variables after initial management in pulmonary arterial hypertension. Circulation 137, 693-704. doi: 10.1161/circulationaha.117.029254

Weatherald, J., Boucly, A., Launay, D., Cottin, V., Prevot, G., Bourlier, D., et al. (2018b). Haemodynamics and serial risk assessment in systemic sclerosis associated pulmonary arterial hypertension. Eur. Respir. J. 52, 1800678. doi: 10.1183/13993003.00678-2018

Weatherald, J., Sattler, C., Garcia, G., and Laveneziana, P. (2018c). Ventilatory response to exercise in cardiopulmonary disease: the role of chemosensitivity and dead space. Eur. Respir. J. 51:1700860. doi: 10.1183/13993003.008602017

Weatherald, J., Boucly, A., Montani, D., Jais, X., Savale, L., Humbert, M., et al. (2020). Gas exchange and ventilatory efficiency during exercise in pulmonary vascular diseases. Arch. Bronconeumol. S0300-S2896:30017-X. doi: 10.1016/j. arbres.2019.12.030

Wensel, R., Francis, D. P., Meyer, F. J., Opitz, C. F., Bruch, L., Halank, M., et al. (2013). Incremental prognostic value of cardiopulmonary exercise testing and resting haemodynamics in pulmonary arterial hypertension. Int. J. Cardiol. 167, 1193-1198. doi: 10.1016/j.ijcard.2012.03.135

Wensel, R., Georgiadou, P., Francis, D. P., Bayne, S., Scott, A. C., Genth-Zotz, S., et al. (2004). Differential contribution of dead space ventilation and low arterial pCO2 to exercise hyperpnea in patients with chronic heart failure secondary to ischemic or idiopathic dilated cardiomyopathy. Am. J. Cardiol. 93, 318-323. doi: 10.1016/j.amjcard.2003.10.011

Wensel, R., Jilek, C., Dorr, M., Francis, D. P., Stadler, H., Lange, T., et al. (2009). Impaired cardiac autonomic control relates to disease severity in pulmonary hypertension. Eur. Respir. J. 34, 895-901. doi: 10.1183/09031936.001 45708

Wensel, R., Opitz, C. F., Anker, S. D., Winkler, J., Hoffken, G., Kleber, F. X., et al. (2002). Assessment of survival in patients with primary pulmonary hypertension: importance of cardiopulmonary exercise testing. Circulation 106, 319-324. doi: 10.1161/01.cir.0000022687.18568.2a

Whipp, B. J., and Ward, S. A. (1998). Determinants and control of breathing during muscular exercise. Br. J. Sports Med. 32, 199-211. doi: 10.1136/bjsm.32.3.199

Yasunobu, Y., Oudiz, R. J., Sun, X. G., Hansen, J. E., and Wasserman, K. (2005). End-tidal PCO2 abnormality and exercise limitation in patients with primary pulmonary hypertension. Chest 127, 1637-1646. doi: 10.1378/chest.127. 5.1637

Zhai, Z., Murphy, K., Tighe, H., Wang, C., Wilkins, M. R., Gibbs, J. S. R., et al. (2011). Differences in ventilatory inefficiency between pulmonary arterial hypertension and chronic thromboembolic pulmonary hypertension. Chest 140, 1284-1291. doi: 10.1378/chest.10-3357

Conflict of Interest: The authors declare that the research was conducted in the absence of any commercial or financial relationships that could be construed as a potential conflict of interest.

Copyright (c) 2020 Laveneziana and Weatherald. This is an open-access article distributed under the terms of the Creative Commons Attribution License (CC BY). The use, distribution or reproduction in other forums is permitted, provided the original author(s) and the copyright owner(s) are credited and that the original publication in this journal is cited, in accordance with accepted academic practice. No use, distribution or reproduction is permitted which does not comply with these terms. 